\title{
ETNOMEDISIN SEBAGAI SOLUSI ALTERNATIF PADA PERMASALAHAN EKONOMI DAN KESEHATAN MASYARAKAT DI DESA BAGAN KECAMATAN PERCUT SEI TUAN, KABUPATEN DELI SERDANG Oleh: \\ Puspitawati, Sulian Ekomila, dan Noviy Hasanah*
}

\begin{abstract}
Indonesia is a multi-ethnic country consisting of hundreds of tribes and cultures who are faced with various problems including health issues. Health and disease are major problems facing the people of Indonesia since prehistoric times. Similarly, the city of Medan percut sei districts are faced with a host of health and disease. At the community in addressing pain and its treatment often make use of modern medical services when their economic conditions are not sufficient. While they can actually use the land in the yard to grow nutritious crops for the first treatment. Indonesia is also rich in ethnic groups that reached more than 370 ethnic and traditional knowledge which is the nation's cultural heritage in the use of herbs for health maintenance and treatment of hereditary diseases. In the study of anthropology known as ethnomedicine treatment. It is very interesting when examined from the standpoint of anthropology, especially about the treatment ethnomedicine.
\end{abstract}

Keys word: ethnomedicine; etyology; personalistic; naturalistic

\section{A. Pendahuluan}

Indonesia dikenal sebagai negara dengan sumber daya hayati kedua terbesar setelah Brasil yang tersebar dari Sabang hingga Merauke. Di Indonesia terdapat lebih kurang 30.000 jenis tumbuh tumbuhan, lebih kurang 7.500 jenis diantaranya termasuk tanaman obat (Kotranas, 2006). Selain itu, Indonesia juga kaya akan etnis yang mencapai lebih dari 370 etnis dan pengetahuan tradisional yang merupakan warisan budaya bangsa dalam memanfaatkan tumbuhan untuk pemeliharaan kesehatan dan pengobatan penyakit secara turun temurun.

Di negara-negara sedang berkembang termasuk Indonesia, masalah kesehatan merupakan masalah yang belum dapat diselesaikan secara memuaskan, sehingga obat bahan alam semakin diminati oleh masyarakat terutama bila dikaitkan dengan beberapa penyakit yang belum dapat ditangani dengan obat konvensional serta adanya rasa khawatir akan efek samping yang

\footnotetext{
* Dosen Program Studi Pendidikan Antropologi, Fakultas Ilmu Sosial, UNIMED
} 
dapat ditimbulkan oleh obat konvensional itu sendiri yang umumnya berasal dari bahan bahan kimia sintetis. Disamping itu, obat bahan alam juga berperan penting dalam sistem ekonomi yang secara nyata telah memberikan kontribusi yang cukup signifikan di sektor ekonomi.

Keanekaragaman etnomedisin sebagai pengetahuan tentang sistem pengobatan yang didasarkan atas makna budaya lokal (asli) dengan strategi integrasi antara kepercayaan dan praktek pengobatan terhadap penyakit tertentu secara turun temurun dan tidak dipengaruhi oleh kerangka berpikir obat konvensional, merupakan aset nasional yang perlu dikembangkan, dilestarikan, dilindungi dan digali potensinya secara optimal sehingga diharapkan dapat diperoleh etnomedisin dengan mutu, keamanan dan khasiat yang semakin baik serta untuk meningkatkan perekonomian masyarakat.

Terkait dengan peningkatan perekonomian masyarakat, maka hal ini dapat diterapkan pada masyarakat kecamatan Percut Sei Tuan-Medan Sumatera Utara. Kondisi geografis masyarakat percut Sei Tuan yang dekat dengan laut, membuat mayoritas dari masyarakat tersebut bekerja sebagai nelayan. Tak terkecuali perempuan meskipun tidak terlibat langsung dalam kegiatan penangkapan ikan, namun berperan dalam proses penjualan, pengawetan (membuat ikan asin, terasi misalnya), maupun pekerjaan lain di samping tugas utamanya sebagai ibu dan isteri. Namun, kencangnya angin barat, tingginya ombak dan naiknya air laut menjadi bencana bagi komunitas nelayan tradisional karena melumpuhkan aktivitas mencari ikan dilaut. Hal ini berimplikasi langsung pada turunnya penghasilan dan ketersediaan pangan keluarga. Perempuan nelayan yang memiliki peran gender sebagai penyedia makanan bagi keluarganya harus mencari pekerjaan kasar lainnya seperti menjadi penjaja makanan kecil, buruh cuci di keluarga nelayan besar atau berdagang baju bekas keliling.

Dengan kondisi tersebut, pendapatan hanya sebagai nelayan tentu tidak selalu cukup untuk menghidupi keluarga. Terlebih saat kondisi sakit, finansial mereka tentu sangat terbatas untuk hal yang satu ini. Apalagi bila harus berobat ke balai pengobatan yang tentunya menuntut biaya yang tidak sedikit untuk ukuran finansial mereka. Jamkesmas (Jaminan Kesehatan Masyarakat) yang ribet proses pengurusannya membuat tidak semua orang dapat menikmati fasilitas ini. Padahal sedianya fasilitas pengobatan ala Jamkesmas ini diharapkan sebagai salah satu way out bagi mereka yang tidak mampu. 
Dengan adanya pembekalan terhadap masyarakat nelayan di kecamatan Percut Sei Tuan tentang etnomedisin diharapkan, dapat menjawab permasalahan perekonomian mereka dan terlebih lagi, memudahkan mereka dalam pertolongan pertama untuk pengobatan tradisional keluarga dengan memanfaatkan halaman pekarangan rumah untuk menanam obat-obatan tradisional tersebut. Manfaat lain yang dapat diperoleh dari kegiatan ini adalah nantinya akan di dapatkan lingkungan yang hijau dan asri di desa nelayan yang umumnya gersang dan kering.

Berdasarkan beberapa pertimbangan sebagaimana yang telah diuraikan tersebut diatas penelitian ini bertujuan untuk: 1) Mengetahui pemahaman masyarakat Desa Bagan Kecamatan Percut Sei Tuan terhadap konsep etnomedisin? 2) Mengetahui praktek praktek etnomedisin pada msyarakat Desa Bagan Kecamatan Percut Sei Tuan Kabupaten Deli Serdang 3). Mengetahui manfaat etnomedisin dalam permasalahan permasalahan ekonomi dan kesehatan yang terdapat pada masyarakat Desa Bagan Kecamatan Percut Sei Tuan Kabupaten Deli Serdang? 4) Mengetahui pendapat warga Desa Bagan Kecamatan Percut Sei Tuan Kabupaten Deli Serdang mengenai manfaat etnomedisin dan pengobatan modern?

\section{B. Metode Penelitian}

Penelitian ini dilaksanakan di Desa Bagan Kecamatan Percut Sei Tuan Kabupaten Deli Serdang. Yang menjadi objek dalam penelitian ini adalah etnomedisin masyarakat Melayu. Meskipun pengetahuan etnomedisin ini dapat ditemukan di daerah manapun tempat etnik Melayu menetap khususnya di wilayah pesisir Pulau Sumatera, tetapi penelitian ini tidak dilaksanakan di seluruh lokasi daerah asal Etnik Melayu, namun hanya dilaksanakan di Desa Bagan saja, dengan alasan keterbatasan tenaga, waktu dan dana yang tersedia.

Kenyataan di lapangan ternyata peneliti tidak dapat menjumpai tempat yang penduduknya $100 \%$ etnik Melayu, sebab di pesisir manapun selalu dijumpai kelompok etnik lain yang berbaur dengan etnik Melayu ini. Sehingga dalam penelitian ini sebenarnya yang terjaring bukanlah etnomedisin Etnik Melayu secara murni, namun ada percampuran dengan etnik lainnya. Begitupun budaya Melayu tetap menjadi yang mendominasi.

Sejak awal penelitian ini direncanakan, peneliti tidak menentukan berapa orang informan yang akan diambil untuk memberikan informasi dalam penelitian ini. Semuanya tergantung situasi lapangan, artinya peneliti akan menambah jumlah infoman 
apa bila dirasakan data yang diperlukan belum memadai. Tetapi bila dianggap informasi yang diberikan oleh beberapa orang informan saja telah mampu untuk menjawab permasalahan yang diajukan maka dengan sendirinya informan tidak akan ditambah. Cara untuk menentukannya adalah bila data yang diperlukan telah jenuh, salah satu indikatornya adalah bila telah terjadi pengulangan pengulangan informasi yang diberikan oleh informan.

Sesuai dengan perspektif yang digunakan yaitu perspektif emik dan etik. Maka informan dan subjek penelitian dipilih melaui dua tahap. Pertama akan dicari informan yang dapat memberikan data dari sudut pandang etik, yakni orang yang dianggap mengetahui dan memahami tentang pengetahuan etnomedisin asli Etnik Melayu. Yang termasuk dalam kelompok ini adalah tokoh masyarakat, tokoh adat atau orang orang yang dituakan. Pemilihan informan dalam kelompok ini adalah secara purposif, informan tipe ini di peroleh sebanyak 4 orang, yakni Kepala Desa Bagan, bidan desa, dan dua orang tokoh masyarakat. Selanjutnya untuk menjaring data dari sudut pandang emik (tingkat individu) telah dipilih orang yang mengalami langsung/ mengetahui dan atau melaksanakan secara langsung praktek etnomedisin tersebut dalam kehidupan keseharian mereka. Pemilihan informan ini juga dilakukan secara purposif. Berdasarkan beberapa ketentuan yang telah disyaratkan diatas, maka diperolehlah informan inti ini sebanyak 5 orang.

\section{Hasil dan Pembahasan}

\section{Pemahaman Masyarakat Desa Bagan Mengenai Etnomedisin}

Etnomedisin merupakan praktek medis tradisional yang tidak berasal dari medis modern. Etnomedisin tumbuh dan berkembang dari pengetahuan setiap suku dalam memahami penyakit dan makna kesehatan. Pemahaman akan penyakit ataupun teori tentang penyakit tentunya berbeda di setiap suku. Hal ini dikarenakan latar belakang kebudayaan pengalaman dan pengetahuan yang dimiliki setiap suku tersebut berbeda dalam memahami penyakit, terutama dalam mengobati penyakit.

Tidak ada seorangpun dari masyarakat Desa Bagan yang tahu ketika ditanyakan mengenai etnomedisin, padahal sebenarnya mereka telah mempraktekan sistem pengobatan tersebut sejak dulu hingga sekarang. Namun ketika ditanya mengenai pengobatan tradisional mereka menjawab mengerti, atau berdasarkan istilah 
mereka sistem pengobatan tersebut mereka kenal sebagai "obat kampung"

Salah seorang warga Desa Bagan yang peneliti wawancarai yakni ibu Rabu (50) menjelaskan bahwa :

"Pada saat dahulu, kami banyak yang mengetahui kegunaan dari tumbuhan-tumbuhan obat yang ada di desa ini. Apalagi di desa ini kan terdiri dari bermacam suku, jadi apa yang tidak diketahui oleh warga yang bersuku melayu, pastinya diketahui oleh suku lainnya seperti Jawa, Nias, Batak dan Tionghoa. Akan tetapi karena saya juga sudah tua sudah banyak lupa, dan sudah banyak obatobatan di warung jadi ya jarang warga menggunakan tumbuhan obat tersebut kalau sakit sekarang ini, tetapi ada juga yang masih menggunakan tanaman obat"

Dari penjelasan ibu Rabu ini peneliti mengetahui bahwa pengetahuan warga Desa Bagan mengenai kegunaan tumbuhan obat untuk mengobati penyakit dahulunya sangatlah banyak. Meskipun kelompok etnik Melayu menjadi kelompok yang dominan, namun karena adanya percampuran dari bermacam suku ini telah yang telah memberi kontribusi berdasarkan tradisi mereka masing masing, maka kini pengetahuan mereka tentang pengobatan ini tidak lagi murni berasal dari khazanah etnomedisin Etnik Melayu saja tetapi telah bercampur dari etnik etnik lainnya seperti Batak, Minangkabau bahkan juga China.

Dengan demikian sesungguhnya pengetahuan mereka telah kian kaya, tetapi dengan bertambah kayanya pengetahuan warga mengenai pengobatan etnomedisin ini bukan menjadikan mereka makin sering menggunakan tanaman atau bahan bahan lainnya sebagai cara untuk mengobati penyakit, kenyataannya mereka justru lebih banyak menggunakan obat obatan yang diproduksi massal dari pabrik pabrik, dengan alasan sebagaimana yang dikemukakan oleh ibu Rabu di atas yakni lebih murah dan dapat dengan mudah diperoleh di warung warung. Dengan semakin berkembangnya obat-obatan modern yang bisa dibeli dengan harga yang murah, maka penggunaan tumbuhan obat semakin berkurang.

Berdasarkan hasil wawancara peneliti dengan Ibu Sofia (58 tahun) cara pengobatan berlandaskan pengetahuan asli tersebut terbagi menjadi dua macam, yakni pengobatan untuk penyakit ringan dan juga pengobatan untuk penyakit berat. Penyakit ringan bisa diobati secara mandiri dengan mencari bahan bahan sendiri lalu meramunya dan menggunakannya. Yang tergolong penyakit ringan itu antara lain demam, sakit perut,batuk, sakit gigi, sakit 
mata, masuk angin, pusing, kecapekan, luka tersayat pisau atau benda tajam, dan lain lain.

Yang tergolong penyakit berat menurut informan ini adalah penyakit yang berhubungan dengan mistik/kena guna guna. Untuk penyakit seperti ini orang tidak akan mampu mengobatinya sendiri, karena itu perlu bantuan dukun untuk mengatasinya. Dukun yang diperlukanpun tidak semua bisa melakukan penyembuhan, hanya beberapa dukun yang mampu.

\section{Praktek Praktek Etnomedisin Yang Masih Tetap Dilakukan Pada Masyarakat Desa Bagan Kecamatan Percut Sei Tuan}

Pengetahuan etnomedisin yang masih tetap dipraktekkan oleh masyarakat Desa Bagan antara lain:

- Untuk mengobati penyakit ringan seperti demam mereka menggunakan daun sirih. Caranya dengan meremas-remas daun sirih sehingga terlihat agak layu dan mengeluarkan aroma, daun sirih tersebut kemudian diletakkan keatas kepala orang yang demam tersebut.

- Untuk mengobati sakit demam khususnya yang diderita oleh anak anak juga bisa digunakan rimpang kunyit dicampur dengan beras yang disebut pilis. Mula mula kunyit dikupas dan beras dicuci, kemudian kunyit dan ditumbuk bersama sama, setelah halus di oleskan ke kening anak yang demam sambil membacakan doa memohon sembuh dari penyakit yang sedang diderita. Doa yang dibacakan terserah, bisa didahului dengan Surat Al Fatihah, lalu membaca Shalawat Nabi, selanjutnya bisa menggunakan bahasa Indonesia.

- Untuk mengobati sakit gigi biasanya mereka menggunakan cengkeh yang dikulum dalam mulut.

- Sakit perut diobati dengan meminum air gambir.

- Apabila terluka seperti tersayat pisau ataupun benda tajam lainnya sebaiknya langsung diobati dengan menggunakan kopi bubuk. kopi bubuk dicampur dengan sedikit air agar menjadi kental, kemudian kopi yang telah kental tersebut dioleskan di bagian tubuh yang terluka tersebut. Menurut beliau biasanya apabila warga Desa Bagan terluka ketika memotong ikan dari hasil tangkapannya di laut, maka sudah mengerti untuk mengoleskan kopi kebagian tubuh yang luka (Informan: Ibu Yuli, 65 tahun).

- Bukan hanya dalam mengobati demam, akan tetapi pada saat setelah melahirkan beliau juga menjelaskan bahwa ibu-ibu di desa ini masih banyak yang melakukan pengobatan 
tradisional. Bagi ibu yang baru melahirkan biasanya melakukan duduk di ganggangan (panggangan). Ganggangan adalah sebuah batu yang terbuat dari tanah liat yang berbentuk seperti panggangan. Kemudian daun sereh, kunyit, laos atau lengkuas, daun pandan wangi di bakar, lalu si ibu yang melahirkan memakai sarung dan melakukan ganggangan diatas daun-daunan yang di bakar tersebut. Fungsi perlakuan ini adalah untuk mempercepat kesembuhan setelah melahirkan, agar ibu yang melahirkan bisa lebih cepat beraktivitas, liang peranakan lebih cepat kering, tidak bau amis dan lebih bugar.

Pengobatan pasca melahirkan ini meskipun sesungguhnya tidak bisa tergolong ringan, tetapi karena proses melahirkan itu adalah suatu proses biasa yang secara alamiah sering dilalui manusia maka menurut informan ini juga tergolong penyakit ringan.

Ibu yang baru melahirkan juga menggunakan bedak panas yang disebut dengan istilah bedak litri. Bedak ini terbuat dari tepung beras, merica, kunyit, jahe, daun pandan. Semua bahan bahan tersebut digabungkan menjadi satu. Bila hendak dikenakan dapat dibalurkan ke seluruh tubuh. Tujuan pembuatan bedak ini berguna untuk melancarkan peredaran darah pasca melahirkan. Biasanya keseluruhan pengobatan pasca melahirkan ini dilaksanakan setelah pulang dari klinik ataupun Rumah Sakit pada saat melahirkan (informan Ibu Sofia, 58 tahun)

- Untuk mengobati penyakit berat seperti kena guna guna tanaman yang dipergunakan sebenarnya biasa saja/tanaman yang umum dimanfaatkan. Sebagaimana yang dijelaskan oleh ibu Sofia. Ketika mengobati sakit Ibu Sofia yang kena guna guna dulu almarhum suami $\mathrm{Bu}$ Yuli memakai buah pinang kaca atau pinang yang masih hijau, pinang kaca digunakan karena mengandung serat yang banyak yang mampu menghilangkan rasa gatal. Dalam hal ini peneliti baru mengetahui ternyata pinang kaca dapat dijadikan sebagai tumbuhan obat. Karena seperti yang diketahui peneliti selama ini bahwa yang biasa dijadikan bahan obat-obatan adalah pinang yang sudah berwarna kuning (matang). Pinang kaca dianggap sebagai tumbuhan yang dapat menghilangkan pengaruh kekuatan mistik. Cara menggunakannya yaitu pinang kaca dikupas, dibelah empat, dicuci lalu direbus bersama dengan jerango dan pucuk pisang asam. Setelah direbus barulah ditaburkan ke kaki bu Sofia. 
$\mathrm{Bu}$ Yuli membenarkan informasi dari Bu Sofia, bahwa memang suaminya sering menggunakan bahan bahan tersebut untuk mengobati penyakit kena guna guna. Namun meski demikian untuk pengobatan mistik ini memang tidak semua orang mampu melakukannya. Meskipun telah tahu obat yang dipergunakan itu bahannya apa saja, tetap belum tentu mampu mengobatinya. Karena mengobati penyakit karena mistik itu ada doa doanya yang hanya diketahui oleh para dukun saja. Doa doa ini umumnya bersifat rahasia. Karena bagi para dukun disanalah letak kekuatannya, sehingga ia tidak akan memberi tahukan pada sembarang orang mengenai jampi jampi/ doa yang digunakannya. Sebab bila semua dukun mengetahuinya maka kepopulerannya sebagai dukun akan mendapat banyak saingan.

$\mathrm{Bu}$ Yuli juga menyampaikan bahwa selain berprofesi sebagai dukun yang mengobati penyakit terkena guna guna, suami beliau juga bertindak sebagai bidan kampung dahulunya, pengertian bidan kampung disini bukanlah orang yang pekerjaannya untuk membantu orang melahirkan, tetapi lebih tepat sebenarnya sebagai dukun, tetapi mereka banyak yang tidak suka dengan sebutan dukun.

\section{Manfaat Etnomedisin Dalam Permasalahan Permasalahan Ekonomi Dan Kesehatan Yang Terdapat Pada Masyarakat Desa Began Kecamatan Percut Sei Tuan Kabupaten Deli Serdang}

Warga Desa Bagan yang mayoritas berprofesi sebagai nelayan tentu saja secara spesifik mempunyai masalah masalah berkaitan dengan keadaan ekonomi mereka yang umumnya berpendapatan rendah. Akibatnya tentu saja berimplikasi pada masalah kesehatan, karena untuk sehat memang dibutuhkan biaya, dan tidak semua orang mampu menjangkau biaya kesehatan, baik dalam hal preventif maupun kuratif.

Mereka memiliki pendapatan yang tidak menentu. Kondisi ekonomi mereka bergantung kepada hasil tangkapan ikan di laut dan tidak ada kepastian akan hasil tangkapan tersebut, terkadang banyak dan lain waktu sedikit, bahkan kadang kadang tidak ada sama sekali. Terutama pada saat terjadi kondisi ekstrem di laut, seperti angin kencang ataupun badai, maka bisa saja pada saat itu nelayan tidak akan bisa menangkap ikan dilaut. Dengan keadaan demikianjangankan untuk biaya berobat, memenuhi kebutuhan makan sehari hari saja mereka sulit. Menghadapi keadaan tersebut biasanya mereka (terutama nelayan buruh akan meminjam uang 
pada juragan). Peminjaman ini akan menjadi ikatan yang sulit untuk diputuskan, karena mereka harus terus bekerja pada juragan yang sama meskipun dibayar rendah. Bagi yang bekerja sendiri biasanya akan meminjam pada rentenir dengan bunga yang tinggi dan mencekik leher. Demikian seterusnya sehingga para nelayan umumnya, kecuali nelayan juragan/toke sukar sekali terlepas dari jerat kemiskinan.

Masalah rezeki/ekonomi ini juga berdampak pada cara mereka mengatasi masalah kesehatan. Apa bila keadaan sedang baik/punya uang mereka akan berobat dengan pengobatan medis/ke bidan desa atau ke dokter di Medan. Tetapi bila sedang tidak punya uang mereka memiliki dua pilihan, tetap memakai pengobatan modern, tetapi hanya membeli obata obatan bebas di pasar yang dapat dibeli dengan harga murah atau akan beralih ke etnomedisin. Hal ini terungkap dari hasil wawancara peneliti dengan bidan desa yang bernama Bu Khoiriah (52 tahun) salah satu bidan di Desa Bagan bahwa :

"Dahulunya apabila warga sakit maka akan langsung berobat ke bidan desa atau membeli obat-obatan generik saja, akan tetapi tidak semua obat-obatan generik tersebut memberikan penyembuhan yang cepat. Karena dianggap telah banyak mengeluarkan biaya dan juga tidak memberikan kesembuhan secara cepat, maka sekarang warga apabila sakit akan mencoba dahulu pengobatan tradisional dengan tumbuhan-tumbuhan obat yang ada di desa Bagan. Karena tentunya tidak mengeluarkan banyak biaya terlebih dahulu".

Apa yang disampaikan oleh bu Khoiriah ini tentunya semakin menjelaskan bahwa pengobatan secara tradisional dengan menggunakan tumbuhan obat yang sangat meminimalkan pembiayaan lebih banyak dilakukan oleh warga desa Bagan pada saat ini. Hal ini tentunya juga meminimalisir pengeluaran pembiayaan hidup warga yang berpenghasilan tidak menetap.

\section{Pandangan Masyarakat Desa Bagan Kecamatan Percut Sei Tuan Kabupaten Medan Terhadap Etnomedisin Dan Pengobatan Modern}

Pendapat masyarakat Desa Bagan terhadap etnomedisin dan pengobatan modern dalam hal ini ada beberapa perbedaan pendapat dari warga. Sebagian dari mereka menganggap lebih baik menggunakan pengobatan etnomedisin dari pada pengobatan modern dengan alasan alasan sebagai berikut: 1). Pengobatan asli bahan bahannya mudah diperoleh karena berasal dari lingkungan 
di sekitar tempat tinggal. Kalaupun harus dibeli, tetap murah harganya; 2). Obat obatan ini lebih alami dibandingkan obat obatan yang berasal dari dokter. Umumnya tidak banyak efek sampingnya karena tidak menggunakan bahan bahan kimia; 3). Dapat dilakukan secara mandiri kapan saja.

Sebagian lagi dari masyarakat menganggap lebih baik melakukan kombinasi/menggabungkan pengobatan etnomedisin dengan yang modern karena keduanya bersifat komplementer. Untuk penyakit penyakit ringan lebih baik berobat sendiri saja dengan memanfaatkan tanaman yang ada di sekitar pemukiman mereka, tapi kalau sudah berat baru ke rumah sakit. Atau sebaliknya setelah mencooba mengobati penyakit yang berat di dokter tapi belum sembuh juga, maka mereka beralih kembali menggunakan cara cara yang tradisional.

\section{B. Kesimpulan}

Masyarakat Desa Bagan Kecamatan Percut sei Tuan Kabupaten Deli Serdang masih mengetahui beberapa pengetahuan etnomedisin:

1. Masyarakat setempat masih tetap mempraktekkan pengetahuan etnomedisin mereka dalam mengatasi penyakit atau pemeliharaan kesehatan

2. Masalah yang berhubungan dengan keadaan ekonomi dan kesehatan yang sering dialami oleh masyarakat desa ini antara lain masalah kekurangan uang dikarenakan memang penghasilan sebagai nelayan tidak menentu. Terkadang banyak, terkadang kurang, tetapi lebih sering justru terjadi kekurangan. Masalah yang berhubungan dengan penyakit umumnya penyakit penyakit yang ada sehari hari seperti batuk, pilek, demam, sakit gigi, sakit perut, sakit mata dan sebagainya.

3. Etnomedisin bisa menjadi solusi bagi permasalahan ekonomi dan kesehatan masyarakat karena dengan memakai bahan bahan yang ditanam/diproduksi sendiri dengan sendirinya telah mengurangi dana yang seharus diperlukan untuk pengobatan. Tetapi yang menjadi persoalan bukan karena tidak bisa dilakukan, hanya masyarakat agaknya enggan untuk melakukan penanaman bahan bahan obat tersebut. Sehingga meskipun sebenarnya ini bisa dijadikan alternatif pemecahan masalah ekonomi dan kesehatannya, namun hanya sedikit saja warga yang bersedia melakukannya. Demikian pula seandainya mereka enggan melakukan penanaman tumbuhan, tetapi ada cara lain untuk mendapatkannya, yakni dengan cara 
membeli dipasar, tetapi inipun agaknya enggan mereka laksanakan.

4. Pendapat masyarakat Desa Bagan terhadap etnomedisin dan pengobatan modern ada beberapa perbedaan, sebagian dari mereka menganggap lebih baik menggunakan pengobatan etnomedisin dari pada pengobatan modern dengan alasan lebih alami dan tidak banyak efek sampingnya. Sementara sebagian yang lain menyatakan lebih baik menggunakan pengobatan modern karena lebih mudah dan mudah didapat, selain itu juga lebih cepat hasilnya dapat dilihat/lebih instan. Sebagian lagi menganggap lebih baik melakukan secara bersamaan/menggabungkan pengobatan etnomedisin dengan yang modern karena keduanya bersifat komplementer.

\section{Daftar Pustaka}

Djekky R. Djoht . Penerapan Ilmu Antropologi Kesehatan dalam Pembangunan Masyarakat. Papua Antropologi Papua Vol.I (1), Agustus 2002 (pdf 267kb)

Foster GM, Anderson BG. Antropologi Kesehatan,terjemahan, Jakarta: Penerbit Universitas Indonesia, 1986.

Handayani L, Maryani H. Mengatasi PenyakitAnak dengan Ramuan Tradisional. Jakarta: Agro Media Pustaka, 2002.

Ika, Afiani Limananti, Atik Triratnawati pada Jurusan Antropologi, Universitas Gadjah Mada, dengan judul penelitian "Ramuan Jamu Cekok Sebagai Penyembuhan Kurang Nafsu Makan Pada Anak: Suatu Kajian Etnomedisin". Penelitian tersebut telah dimuat di Jurnal MAKARA, KESEHATAN, VOL. 7, NO. 1, JUNI 2003.

Meliono, Irmayanti -Budianto pada Departemen Filsafat, Fakultas Ilmu Pengetahuan Budaya, Universitas Indonesia, dengan judul "Dimensi Etis Terhadap Budaya Makan Dan Dampaknya Pada Masyarakat". Penelitian tersebut telah dimuat di Jurnal MAKARA, SOSIAL HUMANIORA, VOL. 8, NO. 2, AGUSTUS 2004. 13

Sudarsono, Harini, Marsono, Obat tradisional dalam naskah kuno sebagai dasar pengembangan manfaat di masa depan. Seminar Menapak Jejak Sejarah Memberi Makna ke Depan. Jogjakarta: Yayasan Pengkajian Naskah dan Sejarah, 2003. 